\title{
A new deep-sea species of Barathronus Goode \& Bean from Brazil, with notes on Barathronus bicolor Goode \& Bean (Ophidiiformes: Aphyonidae)
}

\author{
Jørgen G. Nielsen ${ }^{1}$, Michael M. Mincarone² and Fabio Di Dario²
}

A new species of Barathronus (Ophidiiformes: Aphyonidae) is described from a single, mature male specimen (101 mm SL) bottom trawled on the continental slope of Rio Grande do Norte, northeastern Brazil, between 1,964 and 2,045 m depth. The new species is diagnosed among congeners by the following combination of characters: peritoneum transparent, deep-set eyes not visible, eight fangs on vomer, anal fin rays 69 , predorsal length $42.0 \%$ SL, preanal length $49.5 \%$ SL, penis long, slender, and lacking a pair of lobes at its base, and presence of a ventral flexure of the anterior 2-3 vertebrae. Additionally, morphological data of three specimens of Barathronus bicolor collected in Brazilian waters are presented and compared with those from 51 specimens from the western Central Atlantic.

Uma nova espécie de Barathronus (Ophidiiformes: Aphyonidae) é descrita a partir de um único exemplar macho (101 mm CP) coletado com arrasto de fundo no talude continental do Rio Grande do Norte, nordeste do Brasil, entre 1.964 e 2.045 $\mathrm{m}$ de profundidade. A espécie nova é diagnosticada entre as congêneres pela seguinte combinação de caracteres: peritônio transparente, olhos alojados profundamente e não distinguíveis, oito presas no vômer, nadadeira anal com 69 raios, comprimento pré-dorsal 42,0\% CP, comprimento pré-anal 49,5\% CP, pênis longo, afilado e sem um par de lobos em sua base, e presença de flexão ventral nas 2-3 vértebras anteriores. Adicionalmente, dados morfológicos dos três espécimes de Barathronus bicolor coletados em águas brasileiras são apresentados e comparados com aqueles de 51 espécimes do Atlântico Central ocidental.

Keywords: Teleostei, Deep-sea diversity, Potiguar Basin, Western South Atlantic, Brazilian EEZ.

\section{Introduction}

The Aphyonidae (Ophidiiformes) is composed of six genera and 22 valid species of mostly small to mediumsized, viviparous, bathypelagic and benthopelagic fishes. Diagnostic features of the family include a loose, transparent and gelatinous skin, poorly developed (or not visible) eyes, basibranchial tooth patches absent, and long dorsal and anal fins joined to the caudal fin (Nielsen et al., 1999). Previous records of the family in the western South Atlantic are restricted to two specimens of Barathronus bicolor Goode \& Bean, 1886 and three specimens of Aphyonus gelatinosus Günther, 1878, all collected off southeastern Brazil (Séret \& Andreata, 1992; Franco et al., 2007; Franco, 2010).

Barathronus Goode \& Bean, 1886 is characterized by having a combination of a scaleless, loose, transparent skin, 29-38 precaudal vertebrae, deep-set eyes, first gill arch with 13-35 long rakers, 9-10 caudal fin rays, and one ray in each pelvic fin. The genus currently includes ten valid species (Nielsen et al., 1999; Nielsen \& Møller, 2008).
Four species of Barathronus are reported from the Atlantic Ocean: B. bicolor in the West Atlantic from off South Carolina to off Rio de Janeiro State; B. multidens Nielsen, 1984 from off Florida and Morocco; B. unicolor Nielsen, 1984 from the western North Atlantic $\left(38^{\circ} 28^{\prime} \mathrm{N}\right.$, $70^{\circ} 52^{\prime} \mathrm{W}$ ); B. parfaiti (Vaillant, 1888) from between the Azores and France. Nielsen (1969: 53) listed two specimens of B. parfaiti, the holotype (MNHN 86-554) and a 100mm SL specimen collected in the Azores in 1896 (MOM, uncatalogued). The holotype of B. parfaiti is a poorly preserved $40-\mathrm{mm}$ SL specimen, and few characters stated in the original description of this species can be verified today from examination of the specimen. Additional specimens of Barathronus strongly indicate that the MOM specimen does not belong to B. parfaiti, but rather to an undescribed species of the genus not treated herein. Six species of Barathronus are reported from the Indian and Pacific oceans: B. affinis Brauer, 1906, from off the Maldive Islands, Indian Ocean; B. bruuni Nielsen, 1969, from the western South Indian Ocean; B. diaphanus Brauer, 1906 and B. maculatus Shcherbachev, 1976, both from the Indian and

\footnotetext{
${ }^{1}$ Natural History Museum of Denmark, Universitetsparken 15, DK-2100 Copenhagen, Denmark. jgnielsen@snm.ku.dk ${ }^{2}$ Universidade Federal do Rio de Janeiro (UFRJ), Núcleo em Ecologia e Desenvolvimento Socioambiental de Macaé (NUPEM), CP 119331,27910-970 Macaé-RJ, Brazil. mincarone@macae.ufrj.br; didario@macae.ufrj.br
} 
western Pacific oceans; B. pacificus Nielsen \& Eagle, 1974, from the eastern North Pacific; B. solomonensis Nielsen \& Møller, 2008, known from the Solomon Sea, Pacific Ocean (Nielsen et al., 1999; Nielsen \& Møller, 2008).

In 2011, a deep-sea expedition performed by the R/V Seward Johnson on the continental slope off Rio Grande do Norte State, northeastern Brazil, collected several deep-sea fishes, including one specimen of Barathronus taken at approximately 2,000 $\mathrm{m}$ depth. Comparison with all valid species of the genus (Tables 1-2) revealed that this specimen belongs to a new species, which is described herein. In addition, a 117-mm male specimen of B. bicolor collected off Rio de Janeiro State, between 990 and 994 m depth, represents the third specimen of the species from the western South Atlantic. The three specimens of B. bicolor from Brazilian waters are compared to specimens from the western Central Atlantic.

\section{Material and Methods}

Material examined includes 95 specimens of all valid species of Barathronus and the holotype of the new species described herein (see Comparative Material for a complete list). Measurements and counts (Tables 1-2) follow those of Nielsen et al. (1999). Counts of vertebrae and vertical fin-rays are based on radiographs. Abbreviations: AMS - Australian Museum, Sydney; ASIZP - Academia Sinica, Biodiversity Research Museum, Taipei; BSKU Kochi University, Department of Natural Science, Faculty of Science, Kochi; CSIRO - Commonwealth Scientific and Industrial Research Organization, Hobart; MNHN - Muséum national d'Histoire naturelle, Paris; MNRJ Museu Nacional, Universidade Federal do Rio de Janeiro, Rio de Janeiro; MOM - Musée Oceanographique de Monaco, Monaco; MOVI - Museu Oceanográfico Univali, Piçarras; NPM - Coleção de Peixes, Núcleo em Ecologia e Desenvolvimento Socioambiental de Macaé, Universidade Federal do Rio de Janeiro, Macaé; SAM - South African Museum, Cape Town; USNM - National Museum of Natural History, Washington, D.C.; USU - Universidade Santa Úrsula, Rio de Janeiro; ZIN - Zoological Institute, Russian Academy of Sciences, St. Petersburg; ZMA - Zoölogisch Museum, Universiteit van Amsterdam, Amsterdam; ZMB - Zoologisches Museum, Humboldt-Universität, Berlin; ZMUC - Zoological Museum, Natural History Museum of Denmark, Copenhagen.

Table 1. Meristic and morphometric characters for the western Atlantic species of Barathronus. * From Nielsen (1969; 42 specimens) and Rannou et al. (1975; 9 specimens). ** Based on 10 specimens; tip of rays often broken.

\begin{tabular}{|c|c|c|c|c|c|}
\hline \multirow{2}{*}{$\begin{array}{l}\text { Species } \\
\text { Number of specimens }\end{array}$} & \multirow{2}{*}{$\begin{array}{l}\text { B. linsi } \\
\text { holotype }\end{array}$} & \multicolumn{2}{|c|}{ B. bicolor } & \multirow{2}{*}{$\begin{array}{l}\text { B. multidens } \\
\text { holotype }+ \\
\text { paratype }\end{array}$} & \multirow{2}{*}{$\begin{array}{c}\text { B. unicolor } \\
\text { holotype }+ \\
17 \text { paratypes }\end{array}$} \\
\hline & & $51^{*}$ & 3 & & \\
\hline Distribution & Brazil & $\begin{array}{l}\text { western Central } \\
\text { Atlantic }\end{array}$ & Brazil & North Atlantic & $\begin{array}{l}\text { western North } \\
\text { Atlantic }\end{array}$ \\
\hline Standard Length (SL in mm) & 101 & $58-140$ & 73-117 & $72-83$ & $72-113$ \\
\hline \multicolumn{6}{|l|}{ Counts } \\
\hline Dorsal-fin rays & 78 & $62-78$ & $70-72$ & 72-ca.75 & $63-78$ \\
\hline Caudal-fin rays & 11 & $9-10$ & 10 & 10 & 10 \\
\hline Anal-fin rays & 69 & $51-59$ & $55-58$ & $63-$ ca. 65 & $55-71$ \\
\hline Pectoral-fin rays & 21 & $22-25$ & $22-23$ & $23-24$ & $23-25$ \\
\hline Pelvic-fin rays & 1 & 1 & 1 & 1 & 1 \\
\hline Long rakers on anterior gill arch & 25 & $28-33$ & $28-30$ & $23-24$ & $26-29$ \\
\hline Precaudal vertebrae & 33 & $31-35$ & 34 & $32-33$ & $35-38$ \\
\hline Total vertebrae & 78 & $70-75$ & $70-71$ & $77-79$ & $78-86$ \\
\hline Origin of dorsal fin above vertebra no. & 29 & $23-26$ & $23-25$ & $29-31$ & $29-33$ \\
\hline Anterior anal ray below dorsal ray no. & 12 & $15-20$ & 14-18 & $8-10$ & $7-11$ \\
\hline Anterior anal ray below vertebra no. & 35 & $32-35$ & $32-34$ & 36 & $35-39$ \\
\hline \multicolumn{6}{|l|}{ Measurements in \% SL } \\
\hline Head length & 16.0 & $18.5-22.5$ & $18.0-20.5$ & 17.5 & $16.0-19.5$ \\
\hline Upper-jaw length & 9.3 & $10.0-12.5$ & $10.0-11.0$ & 9.7 & $9.5-11.5$ \\
\hline Predorsal length & 42.0 & $43.5-50.0$ & $42.5-46.0$ & $46.5-51$ & $48.0-54.0$ \\
\hline Preanal length & 49.5 & $53.0-60.0$ & $54.0-61.0$ & 55.0 & $54.0-59.0$ \\
\hline Base of pelvic to origin of anal fin & 40.5 & $39.0-49.5$ & $39.5-45.0$ & $34.5-39.0$ & $42.5-48.5$ \\
\hline Pectoral-fin length & $11.5+$ & $12.5-20.5 * *$ & $12.5-14.5$ & - & $15.0-21.5$ \\
\hline Pelvic-fin length & 14.5 & $11.0-15.5^{* *}$ & $13.0-15.0$ & - & $9.6-11.5$ \\
\hline
\end{tabular}


Table 2. Selected diagnostic characters of all valid species of Barathronus. * Specimen is severely damaged, therefore numbers presented are approximations. ${ }^{* *} \mathrm{P}=$ Pigmented; $\mathrm{T}=$ Transparent.

\begin{tabular}{|c|c|c|c|c|c|c|c|c|c|c|c|}
\hline & \multicolumn{5}{|c|}{ Atlantic } & \multicolumn{6}{|c|}{ Indo-Pacific } \\
\hline & $\begin{array}{c}B . \\
\text { linsi }\end{array}$ & $\begin{array}{c}B . \\
\text { bicolor }\end{array}$ & $\begin{array}{c}B . \\
\text { multidens }\end{array}$ & $\begin{array}{c}B . \\
\text { parfaiti }\end{array}$ & $\begin{array}{c}B . \\
\text { unicolor }\end{array}$ & $\begin{array}{l}B . \\
\text { affinis }\end{array}$ & $\begin{array}{c}\text { B. } \\
\text { bruuni }\end{array}$ & $\begin{array}{c}\text { B. } \\
\text { diaphanus }\end{array}$ & $\begin{array}{c}\text { B. } \\
\text { maculatus }\end{array}$ & $\begin{array}{c}B . \\
\text { pacificus }\end{array}$ & $\begin{array}{c}B . \\
\text { solomonensis }\end{array}$ \\
\hline $\begin{array}{l}\text { Number of } \\
\text { specimens }\end{array}$ & 1 & 51 & 2 & 1 & 18 & 1 & 1 & 6 & 11 & 3 & 1 \\
\hline Sex & 0 & $j+q$ & $\hat{0}$ & juvenile & $\hat{\jmath}+q$ & $\begin{array}{c}\text { juvenile } \\
q\end{array}$ & $\begin{array}{c}\text { juvenile } \\
q\end{array}$ & $\hat{o}+q$ & $\sigma^{2}+q$ & $\hat{o}+q$ & q \\
\hline $\begin{array}{l}\text { Standard Length } \\
\text { (SL in } \mathrm{mm})\end{array}$ & 101 & $58-140$ & $72-83$ & 40 & $72-113$ & 47 & 39 & $59-117$ & $137-230$ & $66-128$ & 100 \\
\hline Dorsal-fin rays & 78 & $62-78$ & 72-ca. 75 & $80-85^{*}$ & $63-78$ & 77 & 81 & $64-73$ & $75-82$ & $71-75$ & - \\
\hline Anal-fin rays & 69 & $46-59$ & 63-ca. 65 & $60-65^{*}$ & $55-71$ & 67 & 73 & $50-59$ & $57-67$ & $62-69$ & - \\
\hline Pectoral-fin rays & 21 & $22-25$ & $23-24$ & 21 & $23-25$ & 22 & 25 & $22-23$ & $23-25$ & $25-26$ & - \\
\hline $\begin{array}{l}\text { Precaudal } \\
\text { vertebrae }\end{array}$ & 33 & $31-35$ & $32-33$ & 37 & $35-38$ & 34 & 36 & $32-33$ & $33-35$ & $37-38$ & 29 \\
\hline Total vertebrae & 78 & $70-75$ & $77-79$ & 84 & $78-86$ & 78 & 86 & $67-75$ & $74-81$ & $83-89$ & 63 \\
\hline $\begin{array}{l}\text { Long gill rakers } \\
\text { on first gill arch }\end{array}$ & 25 & $28-33$ & $23-24$ & 27 & $26-29$ & 20 & - & $25-30$ & $25-35$ & $28-30$ & $13-14$ \\
\hline $\begin{array}{l}\text { Total gill rakers } \\
\text { on first gill arch }\end{array}$ & 26 & - & - & $29-30^{*}$ & - & 24 & 33 & $28-31$ & $25-35$ & $31-35$ & 20 \\
\hline $\begin{array}{l}\text { Fangs on vomer } \\
\text { (right side) }\end{array}$ & 8 & $1-5$ & 11 & - & 4 & - & - & $2-4$ & $2-5$ & $6-8$ & - \\
\hline $\begin{array}{l}\text { Paired lobes at } \\
\text { base of penis }\end{array}$ & no & no & no & - & yes & - & - & no & no & yes & - \\
\hline $\begin{array}{l}\text { Ventral flexure of } \\
\text { anterior vertebrae }\end{array}$ & yes & no & no & - & yes & yes & no & no & no & no & - \\
\hline Peritoneum** & $\mathrm{T}$ & $\mathrm{P}$ & $\mathrm{T}$ & - & $\mathrm{T}$ & $\mathrm{T}$ & $\mathrm{P}$ & $\mathrm{P}$ & $\mathrm{P}$ & $\mathrm{P}$ & - \\
\hline
\end{tabular}

\section{Results}

\section{Barathronus linsi, new species}

urn:1sid:zoobank.org:act:83B15B91-D5A3-4285-90F4B9AAE6AC9060

Figs. 1-4

Holotype. MNRJ 41723, $101 \mathrm{~mm}$ SL, male with fully developed testes, Brazil, Potiguar basin, off Rio Grande do Norte, $04^{\circ} 25.83^{\prime} \mathrm{S}, 36^{\circ} 37.38^{\prime} \mathrm{W}-04^{\circ} 25.87^{\prime} \mathrm{S}$, $36^{\circ} 36.48^{\prime} \mathrm{W}, 1,964-2,045 \mathrm{~m}$ depth, RV Seward Johnson, sta. ArMT84, bottom trawl, 5 June 2011.

Diagnosis. Barathronus linsi can be distinguished from all congeners by the following combination of characters: peritoneum transparent, deep-set eyes not visible, eight fangs on vomer, anal fin rays 69 , predorsal length $42.0 \%$ SL, preanal length $49.5 \%$ SL, penis long, slender, and lacking a pair of lobes at its base, and the ventral flexure of anterior 2-3 vertebrae. Regarding the other Atlantic species of the genus, $B$. linsi differs from $B$. multidens by the presence of a ventral flexure of the anterior 2-3 vertebrae ( $v s$. no flexure), eight fangs on vomer ( $v s .11)$, penis in mature males long and slender (vs. short and thick), predorsal length $42.0 \%$ SL (vs. 46.5-51.0\%), and preanal length $49.5 \%$ SL (vs. 55.0\%). Barathronus linsi differs from $B$. bicolor by the number of fangs on vomer $(8$ vs. 1-5), the ventral flexure of the anterior vertebrae (vs. no flexure), a transparent (vs. bluish) peritoneum, eyes not visible (vs. eyes most often visible), and anal fin rays 69 (vs. 46-59). Barathronus linsi differs from B. unicolor by the number of fangs on vomer ( $8 v s .4)$, predorsal length $42.0 \%$ SL ( $v s .48 .0-54.0 \% \mathrm{SL}$ ), preanal length $49.5 \% \mathrm{SL}$ (vs. 54.0-59.0\% SL), and by the long and slender penis without paired lobes at its base (vs. short and thick penis with lobes). Barathronus parfaiti is known only from a single, poorly preserved, juvenile specimen. However, $B$. linsi and $B$. parfaiti are clearly distinct by the number of precaudal (33 vs. 37) and total (78 vs. 84) vertebrae. 


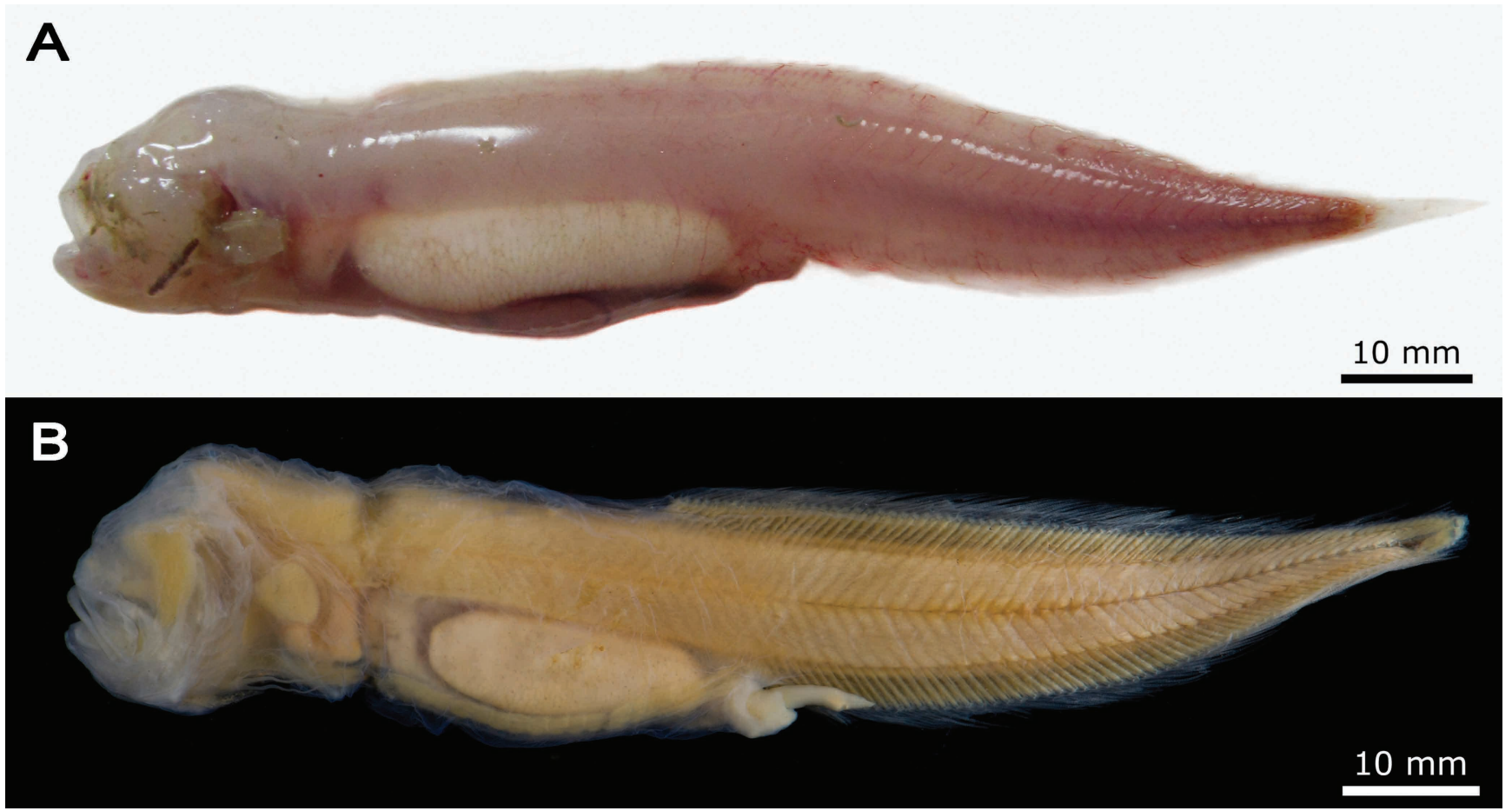

Fig. 1. Barathronus linsi, new species, holotype, MNRJ 41723, $101 \mathrm{~mm}$ SL: (A) recently collected; (B) after two years in preservative (horizontally inverted, right side depicted).

Barathronus linsi and the six Indo-Pacific congeners differ in a series of features, which are summarized in Table 2. In addition, no species of Barathronus have so far been recorded in both the Atlantic and Indo-Pacific oceans. Among Indo-Pacific species, $B$. linsi is most similar to $B$. affinis (known from a single juvenile specimen) in meristic characters, by the presence of a ventral flexure of the anterior vertebrae, and the transparent peritoneum, but they differ by the number of fangs on vomer $(8 v s .2)$ and the number of long gill rakers ( 25 vs. 20).

Description. Meristic and morphometric data of holotype are presented in Tables 1 and 2. Scales absent, skin loose, gelatinous and translucent, sensory pores highly indistinct. Head down-bent, slightly thicker than body. Dorsal, caudal and anal fins united. Dorsal-fin origin well anterior to vertical through midpoint of body, anal-fin origin at midpoint of body. Pelvic fins each with a single, slender ray; pelvic-fin base below hind part of operculum. Pectoral peduncle as broad as long. Eyes not visible. Mouth opening oblique. Nostrils with low rim. Opercular spine covered by skin. Musculi infracarinalis mediales yellowish white; ratio between length and height of "middle fields" (Nielsen, 1969: 9) $c a$. 0.5. Anterior gill arch with 26 prolonged rakers (up to $2.2 \% \mathrm{SL}$ ): four on upper branch, one in the angle and 21 on lower branch. About 30 very small gill filaments $(0.6 \% \mathrm{SL})$. Pseudobranchial filaments apparently absent. Testes large (22\% SL), nearly filling abdominal cavity. Intromittent organ a 9-mm long slender penis, covered proximally by urogenital hood. Lobes at base of penis absent.
Otolith: Otolith $2.2 \mathrm{~mm}$ long, compact, with nearly flat inner face and strongly convex outer face. Outline round, with somewhat depressed predorsal rim. Otolith height 1.2 in length; otolith thickness 1.7 in height. Sulcus moderately large, positioned centrally on inner face and terminating at some distance from otolith rims. A single, undivided, small, narrow colliculum located in anterior part of sulcus. Small bulge on inner face in front of sulcus (Fig. 2).
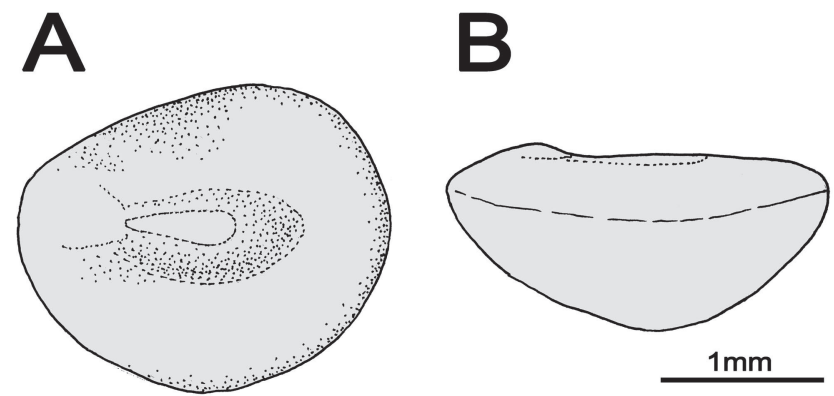

Fig. 2. Sagittal otolith of Barathronus linsi, holotype, MNRJ 41723: (A) median view; (B) ventral view.

Dentition: Palatines edentate. Vomer with two small teeth located between eight distally placed fangs (three broken). Premaxilla with 1-2 rows of small teeth in its full length. Dentary with seven fangs on posterior half and small teeth on anterior half.

Axial skeleton: Precaudal vertebrae 33, all centrae short and high, anterior 2-3 vertebrae ventrally flexed. First vertebra with very short neural spine. Vertebrae 2-8 
with long and slightly laterally compressed neural spines decreasing in length posteriorly. Short parapophyses developed on vertebrae 4-33. Pleural and epipleural ribs absent. Vertebral centrae hourglass-shaped (Fig. 3).

Color. Recently collected specimen (Fig. 1A) overall yellowish to reddish white due mostly to the underlying, somewhat darker, muscle coloration and blood vessels (mostly skin capillaries). No black pigmentation observed either in skin or on peritoneum. Preserved specimen (Fig. 1B) yellowish white (no evidence of bleaching after two years of preservation).

Distribution. Known from the holotype, collected between 1,965 and 2,045 $\mathrm{m}$ depth in the Potiguar basin, of Rio Grande do Norte, northeastern Brazil (Fig. 4).

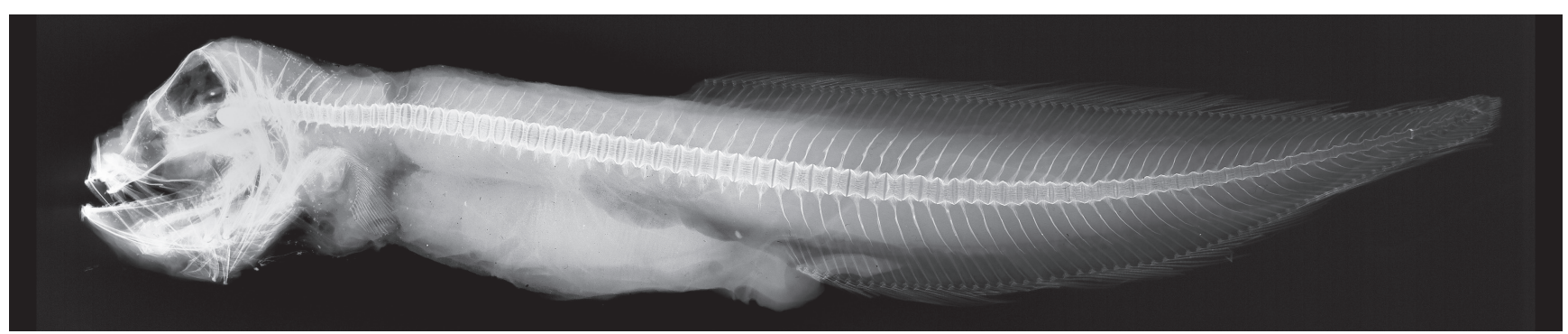

Fig. 3. Radiograph of Barathronus linsi, holotype, MNRJ 41723, 101 mm SL.

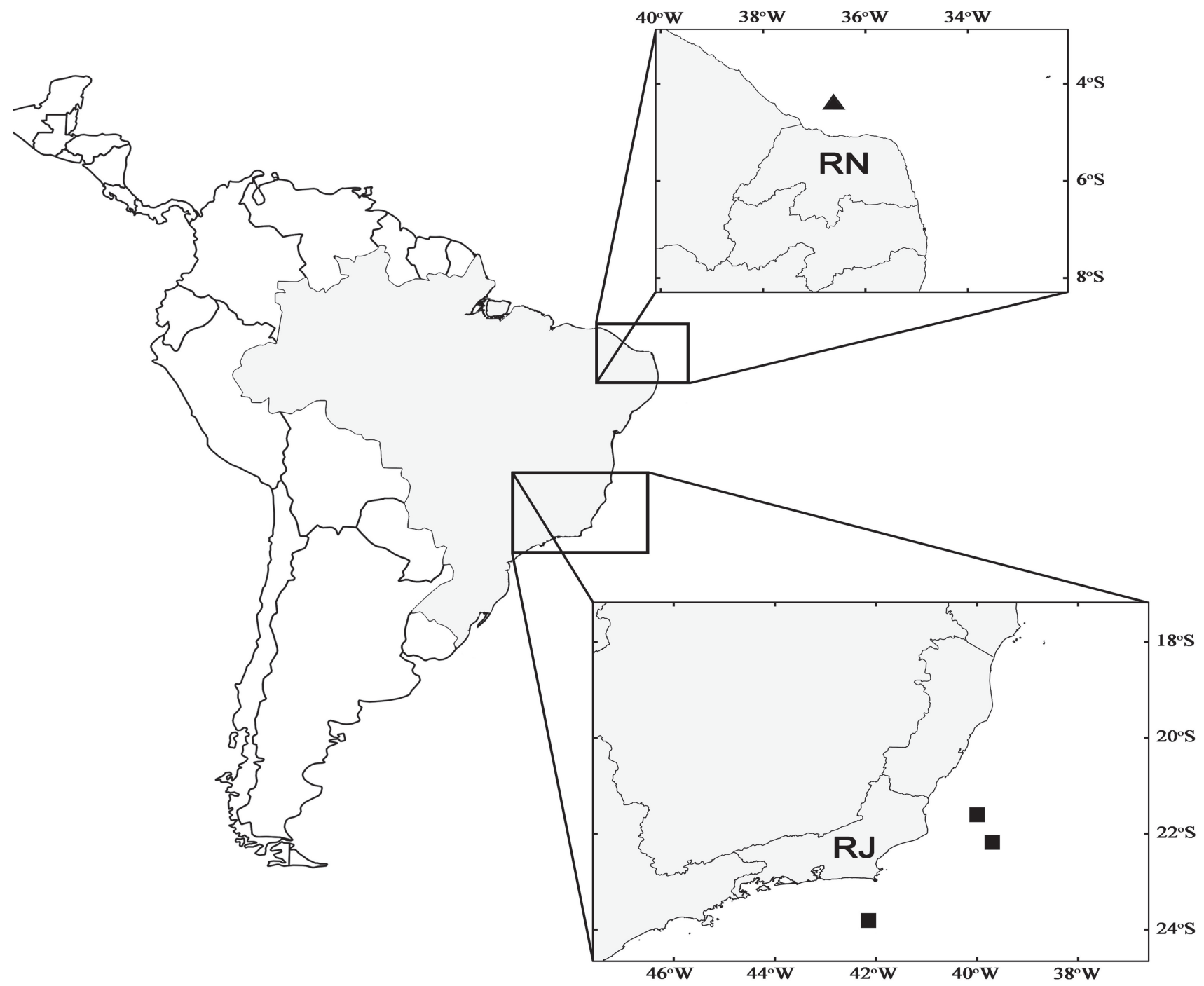

Fig. 4. Records of Barathronus linsi, holotype (triangle) and Barathronus bicolor (squares) in the western South Atlantic. Selected Brazilian states: RN - Rio Grande do Norte, and RJ - Rio de Janeiro. 
Etymology. Named after Prof. Jorge Eduardo Lins de Oliveira (Universidade Federal do Rio Grande do Norte - UFRN), in recognition of his lifetime commitment to the understanding of marine biodiversity of northeastern Brazil. A noun in genitive case.

Notes on Barathronus bicolor in the western South Atlantic. A female specimen ( $73 \mathrm{~mm} \mathrm{SL})$ of B. bicolor, collected in 1987 at $610 \mathrm{~m}$ depth off Rio de Janeiro State, southeastern Brazil (Séret \& Andreata, 1992), represented until recently the single record of this species in the western South Atlantic. Twenty years later, Franco et al. (2007) reported an additional specimen $(98 \mathrm{~mm}$ $\mathrm{SL}$, male) collected between 1,605 to $1,640 \mathrm{~m}$ off Rio de Janeiro State. Meristic and morphometric data of these two specimens and of one additional specimen reported herein (NPM 1243; Fig. 5) are compared to those from the currently known 51 specimens of $B$. bicolor collected in the western Central Atlantic (Table 1). Morphological characters examined are highly congruent between the two clusters, even though the geographic distance between southeastern Brazil and the western Central Atlantic is more than $5,000 \mathrm{~km}$. The only significant difference between examined characters occurs in the penis length, which measures about $4 \%$ SL in the only fully mature male collected off southeastern Brazil (NPM 1243), vs. $10-14 \% \mathrm{SL}$ in specimens from the western Central Atlantic.

\section{Discussion}

Records from both the north and south hemispheres show that B. bicolor is widely distributed in the western Atlantic, although a disjunctive distribution cannot be ruled out given that the species has not been recorded in the South Atlantic north of Rio de Janeiro State. The geographic distribution of $B$. linsi is obviously highly speculative, as the species is known from the holotype. However, it seems reasonable to suppose that $B$. bicolor occurs off northeastern Brazil, and that therefore the distributions of $B$. linsi and B. bicolor probably overlap partially. Barathronus linsi was collected at a depth of approximately $2,000 \mathrm{~m}$, whereas $B$. bicolor is more commonly collected between 500 and $900 \mathrm{~m}$, at least in the western Central Atlantic (Nielsen, 1969; Rannou et al., 1975). If those two benthopelagic species are partially sympatric, it is possible that they might live in different depths on the continental slope.

In the last five years, two new deep-sea species of the Ophidiiformes have been described from Brazilian waters (Nielsen, 2009; this paper), and more than a dozen species of the group were recorded for the first time in the region (Franco et al., 2007; Mincarone et al., 2008; Nielsen et al., 2009). There is also an increase in the knowledge on the diversity of several Brazilian deep-sea fish groups in addition to the Ophidiiformes (e.g., Carvalho et al., 2005; Anderson \& Mincarone, 2006; Mincarone \& Anderson, 2008; Franco et al., 2009; Melo et al., 2009, 2010; Lima et al., 2011; Mincarone et al., 2014 ). That situation results largely from the fact that only in the last decade collections made in recent fishing surveys performed offshore Brazil started to be properly studied. There is still an immense potential for biological discoveries if those collections are further examined, but more collecting efforts in the region are necessary. However, the relatively few deep-sea fishing surveys conducted in Brazilian waters in the last years, especially after the end of REVIZEE (Program for Assessment of the Sustainable Yield of Living Resources of the Exclusive Economic Zone, Brazilian Government), have been totally focused in regions of deep-water oil drilling, such as the Campos Basin, off Rio de Janeiro State. That situation is not negative in itself, but the knowledge on the Brazilian deep-sea diversity will continue to be geographically fragmented and mostly restricted to the few regions were offshore oil drilling is conducted if more encompassing surveys are not planned for the next years.

Comparative Material. Barathronus affinis, Indian Ocean: 1 specimen (Nielsen, 1969: 48). Barathronus bicolor, western South Atlantic: USU 01502, 1, $73 \mathrm{~mm}, 2^{\circ} 46.73^{\prime} \mathrm{S} 42^{\circ} 10.05^{\prime} \mathrm{W}, 610 \mathrm{~m}$, 2 Jun 1987; MOVI 38982, 1, 98 mm, 22 ${ }^{\circ} 12.059^{\prime} \mathrm{S} 39^{\circ} 47.115^{\prime} \mathrm{W}$ to $22^{\circ} 08.548^{\prime} \mathrm{S} 39^{\circ} 46.994^{\prime} \mathrm{W}, 1,605-1,640 \mathrm{~m}, 24$ Aug 2003 ; NPM $1243,1,117 \mathrm{~mm}, 21^{\circ} 40.6019^{\prime} \mathrm{S} 39^{\circ} 58.0555^{\prime} \mathrm{W}$ to $21^{\circ} 37.4510^{\prime} \mathrm{S}$ 4000.0988'W, 989.5-994.0 m, 9 Apr. 2008; western Central Atlantic: 51 specimens (Nielsen, 1969; Rannou et al., 1975).

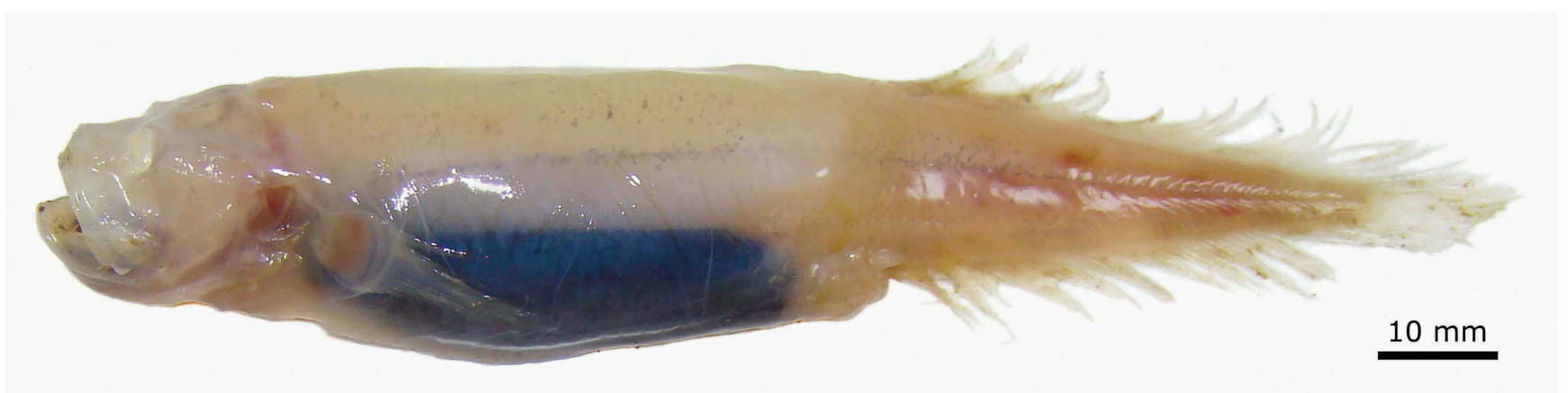

Fig. 5. Barathronus bicolor, NPM 1243, $117 \mathrm{~mm} \mathrm{SL}$, collected off Rio de Janeiro State, Brazil. Photo taken just after collection. 
Barathronus bruuni, Indian Ocean: 1 specimen (Nielsen, 1969: 51). Barathronus diaphanus, Indo-Pacific Ocean: ZMB 17699 , holotype, $117 \mathrm{~mm}$, female, $02^{\circ} 58.8^{\prime} \mathrm{N} 47^{\circ} 6.1^{\prime} \mathrm{E}, 1,289 \mathrm{~m}, 28 \mathrm{Mar}$ 1899; ZMA 104467, 1, 59 mm, female, 1048.6'S 12323.1'E, 918 m, 30 Jan 1900; ASIZP 59-295, 1, 102 mm, female, South China Sea, 1100 m, 13 Jul 1959; Fisheries Research Station Hongkong (uncat.), 1, $92 \mathrm{~mm}$, male, 1940’ $\mathrm{N} 115^{\circ} 30^{\prime} \mathrm{E}, 732-796 \mathrm{~m}$, 7 Jan 1964; ZMUC P771585, 1, 96 mm, female, $13^{\circ} 45^{\prime} \mathrm{S} 156^{\circ} 41^{\prime} \mathrm{E}, 2,255$ 2,283 m, 19 Dec 2006; ZMUC P771586, $112 \mathrm{~mm}$, female, $07^{\circ} 25^{\prime} \mathrm{S}$ 155 44.7'E, 1,012-1,094 m, 27 Dec 2006. Barathronus maculatus, Indo-Pacific Ocean: ZIN 42298, holotype, $157 \mathrm{~mm}$, male,

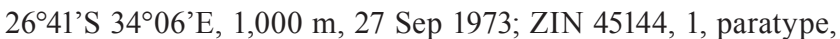
$182 \mathrm{~mm}$, female, $30^{\circ} 16^{\prime} \mathrm{S} 31^{\circ} 18^{\prime} \mathrm{E}, 950-1,050 \mathrm{~m}, 26$ May 1974; USNM 150285, 1, $156 \mathrm{~mm}$, female, 3205'40”N 138 $29^{\circ} 30^{\prime}$ 'E, 386-430 m, 15 Oct 1906; MNHN 1984-371, 1, 144 mm, male, $13^{\circ} 02^{\prime} \mathrm{S} 48^{\circ} 02^{\prime} \mathrm{E}, 1,000-1,525 \mathrm{~m}, 21$ Jan 1975; BSKU 28689, 1, $137 \mathrm{~mm}$, female, $28^{\circ} 53^{\prime} \mathrm{N}, 127^{\circ} 18^{\prime} \mathrm{E}, 820-830 \mathrm{~m}, 16$ Mar 1978; AMS I 24059-013, 1, $187 \mathrm{~mm}$, female, 3329'S 152 $12^{\circ}$ 'E, 942978 m, 2 Sep 1983; AMS 27711-001, 1, 163 mm, male, 3350'S 1515'ㄹ, 960-1,050 m, May 1988; AMS 27638, 1, 230 mm, male, 334'ㅇ 152 06'E 1,020-1,040 m, Jun 1988; SAM 31499, 1, 166 mm, male, 2943.2'S 3143.6'E, 645 m, 23 Aug 1988; CSIRO H 1932-01, 1, 200 mm, female, Great Australian Bight, 16 Mar 1989. Barathronus multidens, Atlantic Ocean: 2 specimens (Nielsen, 1984: 583). Barathronus pacificus, Pacific Ocean: 3 specimens (Nielsen \& Eagle, 1974: 1067). Barathronus parfaiti, eastern North Atlantic: 1 specimen (Nielsen, 1969: 53). Barathronus solomonensis, Pacific Ocean: 1 specimen (Nielsen \& Møller, 2008: 41). Barathronus unicolor, Atlantic Ocean: 18 specimens (Nielsen, 1984: 579).

\section{Acknowledgments}

We thank Rob Robins (UF) and Jules Soto (MOVI) for loan of specimens and for providing morphological data, and Marcelo R. Britto (MNRJ) for curatorial assistance. Werner Schwarzhans (Hamburg) prepared the otolith drawing, and Marcus Krag (ZMUC) provided the photo of the preserved holotype. Two anonymous reviewers provided insightful comments to the manuscript. This study is part of the Talude Project, an initiative coordinated by Universidade Federal do Rio Grande do Norte and CENPES/PETROBRAS. Financial support to MMM and FDD was provided by CAPES, FAPERJ and CNPq.

\section{References}

Anderson, M. E. \& M. M. Mincarone. 2006. Studies on the Zoarcidae (Teleostei: Perciformes) of the southern hemisphere. IX. A new species of Pachycara from the southwestern Atlantic. Zootaxa, 1177: 21-26.

Brauer, A. 1906. Die Tiefsee-Fische. I. Systematischer Teil. In: Chun, C. (Ed.). Wissenschaftliche Ergebnisse der Deutschen Tiefsee-Expedition auf dem Dampfer "Valdivia" 1898-1899. Vol. 15. Jena, Gustav Fischer.

Carvalho, M. R., U. L. Gomes \& O. B. F. Gadig. 2005. Description of a new species of skate of the genus
Malacoraja Stehmann, 1970: the first species from the southwestern Atlantic Ocean, with notes on generic monophyly and composition (Chondrichthyes: Rajidae). Neotropical Ichthyology, 3: 239-258.

Franco, M. A. L. 2010. Barathronus bicolor Goode \& Bean, 1886. Pp. 358-359. In: Lavrado, H. P. \& M. S. Brasil (Eds.). Biodiversidade da Região Oceânica Profunda da Bacia de Campos: Megafauna e Ictiofauna Demersal. Rio de Janeiro, SAG Serv.

Franco, M. A. L., A. C. Braga, G. W. A. Nunan \& P. A. S. Costa. 2009. Fishes of the family Ipnopidae (Teleostei: Aulopiformes) collected on the Brazilian continental slope between $11^{\circ}$ and $23^{\circ} \mathrm{S}$. Journal of Fish Biology, 75: 797-815.

Franco, M. A. L., P. A. S. Costa \& A. C. Braga. 2007. New records of Aphyonidae (Teleostei: Ophidiiformes) from South-west Atlantic. Journal of Fish Biology, 71: 908-912.

Goode, G. B. \& T. H. Bean. 1886. Description of thirteen species and two genera of fishes from the "Blake" collection. Bulletin of the Museum of Comparative Zoology at Harvard College, 12: $153-170$.

Günther, A. 1878. Preliminary notices of deep-sea fishes collected during the voyage of H.M.S. 'Challenger'. Annals and Magazine of Natural History, Series 5, 2: 17-28.

Lima, A. T., P. A. S. Costa, A. C. Braga, G. W. A. Nunan \& M. M. Mincarone. 2011. Fishes of the family Sternoptychidae (Stomiiformes) collected on the Brazilian continental slope between $11^{\circ}$ and $23^{\circ} \mathrm{S}$. Zootaxa, 2742: 34-48.

Melo, M. R. S., A. C. Braga, G. W. A. Nunan \& P. A. S. Costa. 2010. On new collections of deep-sea Gadiformes (Actinopterygii: Teleostei) from the Brazilian continental slope, between $11^{\circ}$ and $23^{\circ} \mathrm{S}$. Zootaxa, 2433: 25-46.

Melo, M. R. S., G. W. A. Nunan, A. C. Braga \& P. A. S. Costa. 2009. The deep-sea Anguilliformes and Saccopharyngiformes (Teleostei: Elopomorpha) collected on the Brazilian continental slope, between $11^{\circ}$ and $23^{\circ} \mathrm{S}$. Zootaxa, 2234: $1-20$.

Mincarone, M. M. \& M. E. Anderson. 2008. A new genus and species of eelpout (Teleostei: Zoarcidae) from Brazil. Zootaxa, 1852: 65-68.

Mincarone, M. M., F. Di Dario \& P. A. S. Costa. 2014. Deepsea bigscales, pricklefishes, gibberfishes and whalefishes (Teleostei: Stephanoberycoidei) off Brazil: new records, range extensions for the south-western Atlantic Ocean and remarks on the taxonomy of Poromitra. Journal of Fish Biology, 85: 1546-1570.

Mincarone, M. M., J. G. Nielsen \& P.A. S. Costa. 2008. Deepsea ophidiiform fishes collected on the Brazilian continental slope, between $11^{\circ}$ and $23^{\circ} \mathrm{S}$. Zootaxa, 1770: 41-64.

Nielsen, J. G. 1969. Systematics and biology of the Aphyonidae (Pisces, Ophidioidea). Galathea Report, 10: 7-88.

Nielsen, J. G. 1984. Two new, abyssal Barathronus spp. from the North Atlantic (Pisces, Aphyonidae). Copeia, 1984: 579-584.

Nielsen, J. G. 2009. A revision of the bathyal genus Luciobrotula (Teleostei, Ophidiidae) with two new species. Galathea Report, 22: 141-156.

Nielsen, J. G., D. M. Cohen, D. F. Markle \& C. R. Robins. 1999. FAO species catalogue. Volume 18. Ophidiiform fishes of the world (Order Ophidiiformes). An annotated and illustrated catalogue of pearlfishes, cusk-eels, brotulas and other ophidiiform fishes known to date. FAO Fisheries Synopsis. No. 125, Vol. 18. Rome, FAO. 
Nielsen, J. G. \& R. J. Eagle. 1974. Description of a new species of Barathronus (Pisces, Aphyonidae) and four specimens of Sciadonus sp. from the eastern Pacific. Journal of the Fisheries Research Board of Canada, 31: 1067-1072.

Nielsen, J. G. \& P. R. Møller. 2008. New and rare deep-sea ophidiiform fishes from the Solomon Sea caught by the Danish Galathea 3 Expedition. Steenstrupia, 30: 21-46.

Nielsen, J. G., F. Uiblein \& M. M. Mincarone. 2009. Ocellusbearing Neobythites species (Teleostei: Ophidiidae) from the West Atlantic with description of a new species. Zootaxa, 2228: 57-68.

Rannou, M., J. G. Nielsen \& J. -C. Hureau. 1975. Note sur quelques Aphyonidae de l'Atlantique Nord (Téléostéens, Ophidioidei). Bulletin du Muséum national d'Histoire naturelle, 3: 1249-1257.
Séret, B. \& J. V. Andreata. 1992. Deep-sea fishes collected during cruise MD-55 off Brazil. Cybium, 16: 81-100.

Shcherbachev, Y. N. 1976. New species of the family Aphyonidae from the Indian Ocean (Pisces, Ophidioidea). Voprosy Ikhtiologii, 16: 162-165.

Vaillant, L. 1888. Expéditions scientifiques du Travailleur et du Talisman pendant les années 1880, 1881, 1882, 1883. Poissons. Paris, G. Masson.

Submitted March 6, 2014 Accepted October 1, 2014 by Marcelo Ribeiro de Britto Published March 31, 2015 